\title{
Density, Energy and Metabolism of a proposed smart city
}

\author{
Dr. Anindita Mandal ${ }^{1}$ and ${ }^{*}$ Dr. Hugh Byrd 2 \\ Luleå Tekniska Universitet, Sweden 1 \\ School of Architecture \& Design, University of Lincoln, UK 2 \\ 1E mail: aninditamandal@yahoo.com ,2 E mail: hbyrd@lincoln.ac.uk
}

\begin{tabular}{|l|}
\hline A R T I C L E I N F O: \\
\hline Article history: \\
Received 2 June 2017 \\
Accepted 13 June 2017 \\
Available online 16 June 2017 \\
\hline Keywords: \\
Smart cities; \\
Energy; \\
Waste; \\
Blackouts; \\
Density; \\
Mumbai; \\
Globalization; \\
Urban sprawl.
\end{tabular}

This work is licensed under a Creative Commons Attribution NonCommercial - NoDerivs 4.0. "CC-BY-NC-ND"

\begin{abstract}
A B S T R A C T
This paper reports on a detailed analysis of the metabolism of the Island City of Mumbai should the Indian Government's proposal for 'smart' cities be implemented. It focuses on the environmental impact of increased population density achieved by demolishing existing medium-rise (3-5 storey) housing and replacing it with the proposed high-rise (40-60 storey) towers. The resulting increase in density places a burden on the demand on such things as electricity and water and simultaneously increases the output flows of drainage, solid waste and greenhouse gas production.

An extended urban metabolism analysis is carried out on a proposed development in Mumbai (Bhendi Bazaar) that has been put forward as an exemplar case study by the Government. The flows of energy, water and wastes are calculated based on precedents and from first principles. The results of the case study are then extrapolated across the City in order to identify the magnitude of increased demands and wastes should the 'smart' city proposals be fully realised.
\end{abstract}

Mumbai is the densest city in the world. It already suffers from repeated blackouts, water rationing and inadequate waste and sewage treatment. The results of the study indicate, on a per capita basis, increasing density will have a significant further detrimental effect on the environment.

JOURNAL OF CONTEMPORARY URBAN AFFAIRS (2017) 1(2), 57-68.

https://doi.org/10.25034/ijcua.2017.3648

wWw.ijcua.com

Copyright (c) 2017 Journal Of Contemporary Urban Affairs. All rights reserved

\section{Introduction}

In the study of the relationship between urban form and resource consumption, there are differing conclusions concerning the impact of dense urban form. For example, reduced transport energy consumption has been shown to correlate with increased urban density (Newman \& Kenworthy, 1989), household space heating energy consumption reduces with compact house forms (Rode et al, 2014) and more general unsupported claims are also made (Leung, 2016; Albino et al, 2015; Nia, 2017). However, other studies have indicated that $\mathrm{CO}_{2}$ emissions from transport and electricity consumption per capita show little correlation with the density of urban areas (Hammer et al, 2011) and there is evidence that dispersed urban forms are more energy efficient when disruptive technologies such as photovoltaics to charge electric vehicles (the more likely technologies of the future) (Byrd et al 2013) are widespread and there is empirical evidence demonstrating that compact residential building forms are less energy efficient (Myers et al, 2005; Byrd et al 2012).

However, policies on urban form tend to favour compaction but there is little evidence of what densities urban form should target to optimise resource consumption (Steadman, 2015). While some studies have indicated an optimum density of about 18 dwellings per $\mathrm{Ha}$ (Gosh et al, 2006) most policies advocating increased density (Sridhar, 2010) stay clear of a density target which can result in the impression that the denser; the more efficient. If that is the case, the

*Corresponding Author:

School of Architecture \& Design, University of Lincoln, UK hbyrd@lincoln.ac.uk 
consequences of urban forms of very highdensity need to be understood and the implications back-casted to inform cities with policies of increased compaction.

This research concerns the densest city in the world, Mumbai, and the environmental impact of the proposed redevelopment proposals that are likely to increase densities from about 3,500persons per hectare to about 5,000, achieved by demolition of existing 3-5 storey height buildings and replacing them with towers averaging 40 floors. What has become known in Mumbai as 'vertical with a vengeance' (Rathod, 2012).

The study investigates the environmental impact of a proposed redevelopment of a 16.5-acre site. Of the many redevelopment proposals in Mumbai, this is in the most advanced stage and is an exemplar for both Mumbai in its ambition to become a 'global city' and the Indian Government who have identified it as a key development in their proposal to achieve 100 'smart' cities (Government of India, 2015).

The study firstly compares the existing urban form with the proposed form. For example, numbers and heights of buildings, density of dwelling and population, parking provision, open space, landscaping and street frontages. It uses the extended urban metabolism model (Newman et al, 1996) as a basis of analysis and predicts the flows of water supply (reticulated and rainwater harvesting), drainage, solid waste, electricity supply, potential for solar energy, fuel for transport, carbon dioxide production and sequestration.

From the results of the 16.5-acre site, the analysis is then extrapolated to the overall impact if similar developments were to be carried out, as is proposed, across all of the Island city of Mumbai. The results indicate that metabolism does not increase linearly (on a per capita basis) with density but accelerates instead. The results also indicate that the compact urban form increases dependence on infrastructure security and that the increased demand of water and electricity is unlikely to be supplied in a reasonably reliable and secure manner. Furthermore, the outputs (waste water, solid wastes, and carbon dioxide production) would increase disproportionately resulting in both health and accelerated climate change issues. The Indian Government (2015) has claimed this type of development to be sustainable, environmentally friendly and 'smart'.
This research indicates the opposite may be more likely.

\section{Background to the development Proposals}

The Island City of Mumbai trebled in population over a period of about 50 years (1931-1981) mainly due to rural-to-urban migration (Census of India, 2011). The population peaked and has subsequently experienced a marginal decline as the suburbs have grown. The migrants into the City were protected by the Mumbai Rent Restriction Act (1939) limiting returns on landlord's investments and resulting in disrepair of the housing stock. As a result, in 1969, the "cess" tax was introduced and a levy placed on landlords by the municipal authorities who took over property repairs. Regulated rent levels combined with the 'cess' tax made redevelopment financially unattractive. Added to this were limitations on the ratio of site area to floor area of developments (FSI). In the first Development Plan of Bombay (1964), FSI was limited to 1.66. But with few new developments and, in order to try and encourage developers, this was eased to 2 in 1984 and then 3 in 1991 and 4 in 2009. These inducements had little impact and relatively few high-rise housing was built. The 'cessed' property (generally 3-5 storeys) predominated (Bertaud, 2013).

The cessed properties did not conform with the image that the municipal authorities wanted to see of the City that was the financial capital of India. In 2011, Mumbai hosted the Tall Building conference and announced its proposals to redevelop the city by demolition of cessed property and replacing it with towers with the intention of being perceived as a "global" city (CBTUH, 2010). Further FSI incentives were again introduced in 2009 by Development Control Rules (DCR 33(9)) provided developments were of a significant scale. This triggered new development proposals and one of the first and largest developments was proposed at Behndi Bazaar, Ward $C$ in the Island City. A 16.5 acre site containing 247 buildings (typically $3-5$ storey) are due to be demolished and replaced by 30 towers of between 40 to 60 floors (a built-up area of almost 11 times greater than the site area).

\section{From global to smart city}

In 2015, the Indian Government proposed 100 "smart" cities (Government of India, 2015a) and named Behndi Bazaar as its exemplar development that was a flagship of 'smartness'. Although the definition of a 'smart city' can be vague (Albino et al, 2015) the Government has 
clearly defined their intentions (Government of India, 2015b)| that are summarised below:

i. adequate water supply

ii. Assured electricity supply

iii. Sanitation, including solid waste management iv. Efficient urban mobility and public transport $\checkmark$. Affordable housing, especially for the poor Vi. Robust IT connectivity and digitalization vii. Good governance, especially e-Governance and citizen participation,

viii. Sustainable environment

ix. Safety and security of citizens, particularly women, children and the elderly

$X$. health and education

$x i$. Reduce congestion, air pollution and resource depletion

At least half of these criteria are environmental objectives, which can be measured and reasonably accurately predicted. Because, governance, health and education policies could be implemented without redevelopment, this study focuses on all the environmental elements that are a direct result of the Governments 'smart' proposals.

\section{Method of analysis}

In order to test the claims that the exemplar development met the 'smart' criteria put forward by the Government, the study was undertaken in three stages:

1) analyse the physical characteristics of the new exemplar development and compare these with the existing,

2) evaluate the environmental performance of both the existing and new for comparative purposes,

3) Extrapolate the results of the case study across the whole of the Island City to establish the full impact of a 'smart' city.

\section{Data collection of the development}

Data was collected from various primary and secondary sources including; physical surveys during site visits, from local government agencies, NGOs, the construction industry and desk-based research.

The Mumbai Transformation and Support Unit provided information and maps of cessed properties of the seven wards on Mumbai City and data for the 1,135 projects approved for redevelopment, under DCR 33(7), in the Island city. These data were used in extrapolating the result of the case study to the district level. The Building Proposals Department of Mumbai provided the master plans and area statement for the Bhendi Bazaar case study. Surveyors for the Bhendi Bazaar project provided detailed floor plans and area statements of the existing buildings on the site and a master plan of the proposed development.

This data allowed an analysis of the physical characteristics of the existing and new developments. A three-dimensional model of both the existing and proposed developments was constructed (Figures 1 \& 2). This was used to establish the morphological changes (building heights, street widths, parking provision, roof areas, open space, landscaping and other aspects of built form). Demographic changes (population density, total population) were based on census data for the existing and the developer's calculations for the proposed development together with an assessment of population based on space provision.

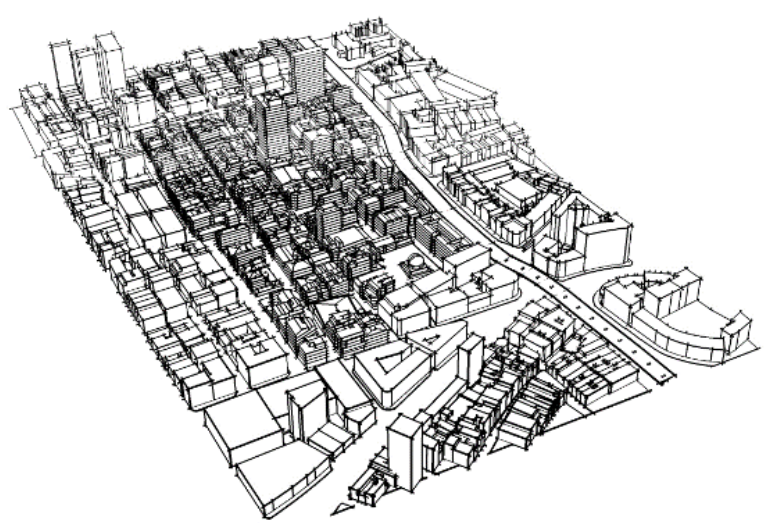

Figure 1. The existing site at Bhendi Bazaar on the Island City of Mumbai.

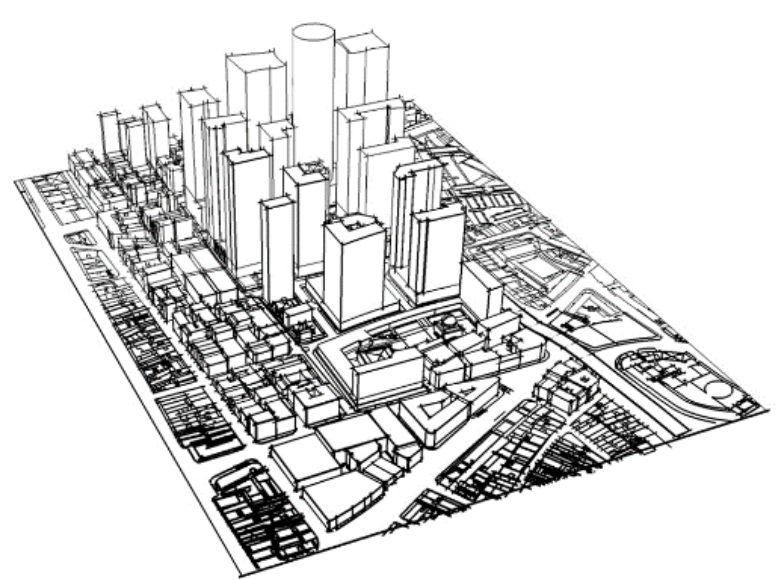

Figure 2. The proposed development that is claimed to be an example for 'smart' cities in India.

Understanding the magnitude of the built form and population increase of the development allowed an analysis of the additional resources 
required for the new development and hence and assessment of the environmental impact.

\subsection{Measuring the environmental impact}

The method used to predict the environmental impact of the development proposals was based on the extended urban metabolism model. This provides a basis for measuring flows of resources that are both consumed by and flow from the city. The study focused on the operational flows rather than embodied resources in the materials of the buildings and infrastructure. While the latter are of importance, they are relatively small over the lifecycle of urban structures and the study does not question whether or not redevelopment should occur; only the appropriateness of the proposed built form.

The flows of resources consist of water and energy as inputs and wastes and pollution as outputs. Water inputs include reticulated supplies from the various dams outside the City as well as rainwater harvesting. Energy includes electricity from the grid as well as potential electricity generated from roof-mounted photovoltaics. It also includes fuels required for transport as well as carbon sequestration by landscape proposals. The outputs include wastewater, solid wastes and carbon dioxide production.

If the Government's claims are correct, then the compaction of built form should result in a proportionate reduction (or at least no increase) of the inflow of resources and outflow of waste products per capita due to efficiencies of scale and improved infrastructure.

Since the development has not been constructed, the flows for the proposed development were predicted based partly on empirical evidence from precedents and supported by calculation from first principles. The full extended urban metabolism analysis together with the calculations and resulting data can be viewed at Mandal (2015).

For example, the predicted electricity consumption was based on the empirical evidence of energy use in different residential built forms in Sydney (Myors et al, 2005), a subtropical climate. This research found that metered energy use, in a sample of over 3,500 different house units, increased with the height of residential developments due mostly to energy consumed in common areas (corridors, car parks, pumping of water and wastes).

Therefore, in order to calculate the energy use in the proposed development of the Mumbai case study, all the energy use in the building was calculated including, for example, private and common lighting, air-conditioning, air extraction in basement car parks, pumping of water, passenger lifts. The energy use was calculated based on the energy rating and hours of operation. The carbon dioxide emissions form electricity generation are calculated based on electricity consumption and the carbon emission content of the generating fuels (mostly coal in this case). Transport energy was based on the number of private vehicles (both cars and 'twowheelers') in the development, their travel frequency and travel distance. While frequency and distance of travel was considered to be similar for both the new and existing developments, the number of car parking spaces in the proposed development is significantly greater. The potential of renewable energy from photovoltaics (PV) was calculated based on available roof area and typical efficiencies of PV installations. Similarly, water consumption was based on the number of occupants, type of appliances and duration of use and wastewater calculations are directly related to water supply.

\subsubsection{Environmental dynamics}

Increased consumption of resources and production of wastes is not necessarily linear with the increase in population. The provision of new facilities induces an increased rate of consumption. Anticipated resource efficiency from the technologies of the new development are unlikely to be achieved due to behavioural responses; an issue in Mumbai identified by Yelda (2006) concerning the dynamics of environmental problems in Mumbai.

For example, the provision of additional 3,000 new car parking spaces in a city that has few existing parking spaces, induces people, particularly in a developing economy, to buy a car. As a conservative estimate, this study assumed that only $80 \%$ of the new parking spaces would be filled. However, since car ownership in the City was restricted due to a lack of car parking spaces, the new provision has significant consequences on energy consumption and subsequent pollution.

Similarly, a significant increase in energy use is attributed to air-conditioning due to a combination of an increased size in residential units, increased cooling loads because of the loss of mutual shading from low to high-rise built form and an increasing ownership (for both status and comfort purposes) of air-conditioning units (Tembhekar, 2009). This is also apparent in the 
retail areas of the development where the traditionally naturally ventilated shallow-plan retail spaces along street frontages are replaced, in the new development, by deep-plan retail outlets that are necessarily dependent on air conditioning.

In the case of water consumption, the increase will not be linear with the additional population since the new development offers significant additional means for water usage. While many of the existing cessed properties have communal washing facilities, the new development offers each individual unit outlets for toilets, showers and washing facilities. Showers and washing machines. This results in not only an increase in the number of water-consuming appliances but also offers the opportunity of increased duration of use.

In the common areas, the increased amount of container planting (used as a mechanism to comply with planning requirements for increased landscaping) demands an additional water supply, unlike trees planted in the ground. The significant increase in the number of cars also results in a proportionate increase in car washing.

\subsubsection{The results; spatial and demographic characteristics.}

With the exception of the existing religious structures mosque and one tower block, the whole site is to be demolished and rebuilt. Figure 3 compares the number of existing and proposed buildings on the site. The fine urban grain of the cessed buildings is lost to large individual buildings resulting in a tenfold reduction in the total number of buildings. Figure 4 indicates the number of proposed tower blocks the highest being 62 floors.

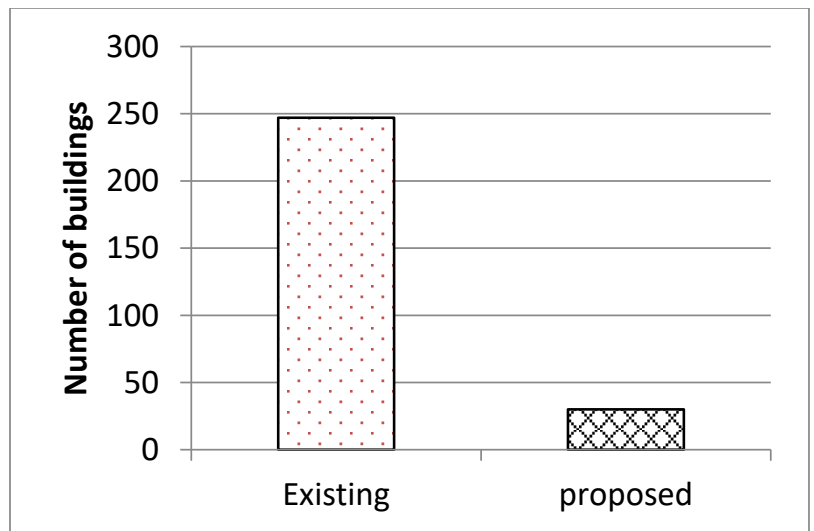

Figure 3. Comparison of the number of buildings for the existing and proposed development.

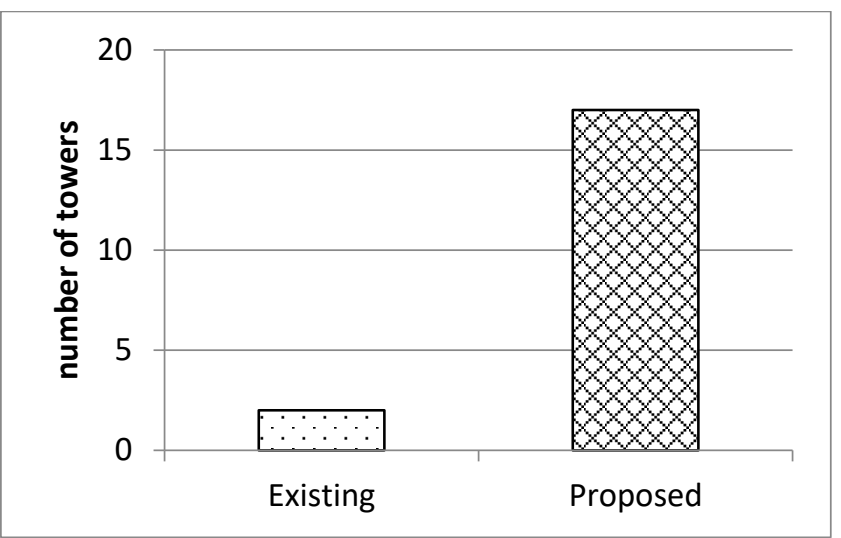

Figure 4. Comparison of the number of residential towers for the existing and proposed development.

These statistics explain why the development proposals have been named "vertical with a vengeance" and the increase in FSI, to almost 4.8 , is indicative of the financial incentive that has been historically hampered by restrictions on the permitted FSI.

Related to this is the density of the development (Figure 5) that has increased by over $25 \%$ to almost 1000 units per hectare. However, the population density of individual units is likely to decrease as the unit sizes have increased by an average of $20 \%$. This potentially results in more space per person in the units but assumes that the increased space standards will be realised rather than increased numbers for each tenancy to fill them up to previous standards.

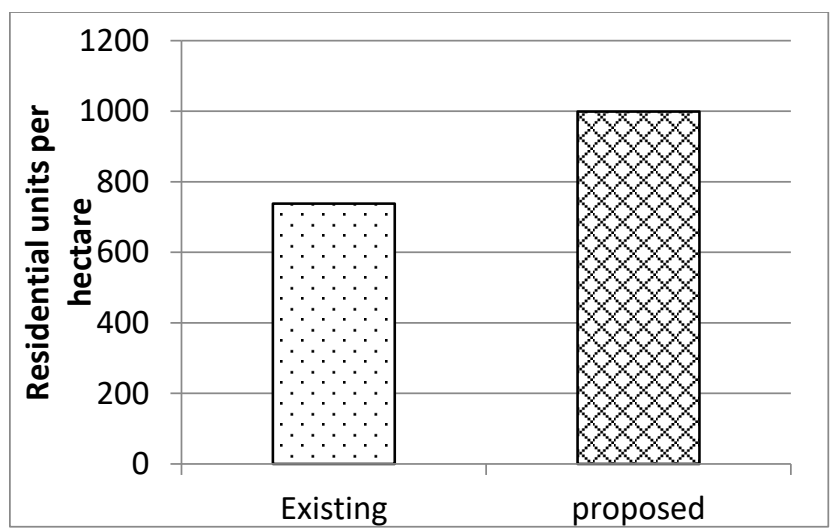

Figure 5. Comparison of the density of residential units per hectare.

The external open space of the proposed development is greater due to the site coverage slightly decreasing from $90 \%$ to $73 \%$ of the total site. However, the open space per person has reduced to 1.07 sq. $\mathrm{m}$ per person, from $1.27 \mathrm{sq} . \mathrm{m}$ per person which is only about $1 / 7$ th the recommendation of the World Health Organisation (sustainablecitiesnetwork, 2011). 
The large podiums have replaced the small streets and alleyways resulting in a significant reduction (63\%) in the perimeter length (active frontages) of all buildings at ground level, much of which is dedicated to small commercial enterprises in the existing development. This is likely to reduce the number of small retail businesses that spread onto the pavement and result in larger units that are spread deeper under the new blocks and become dependent on airconditioning and artificial lighting.

The number of trees on the site has increased by over 700 with about $40 \%$ of these being in containers on the roofs of podiums. These trees will assist with planning compliance for the development, but trees in containers on the flat roofs of the podiums will offer little beneficial cooling or carbon sequestration due to their limited size. They will also require constant watering outside the monsoon period.

\subsection{Environmental consequences}

\subsubsection{Water collection and consumption}

Water demand in the new development (Figure 6) is calculated to be more than double the existing (232\% increase). This is partly due to the cleaning required to the increased amount of common areas and also the amount of trees and shrubs (above ground level) that require irrigation outside the monsoon period. However, the bulk of increased water usage comes from greater use within apartments. The reduction in shared bathing/toilet facilities, increased number of private water taps (sink, basins, showers, washing machine) and the 'take-back' effect of potentially more efficient water control systems being offset by a change of behaviour in the use of the appliances (duration of use of bathrooms or use of washing machines).

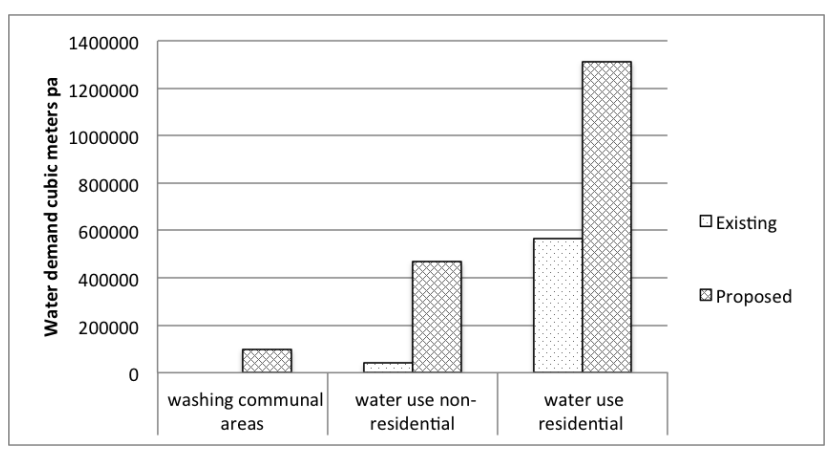

Figure 6. Comparison of existing and proposed water demand by different users.

The reduction in site coverage and the taller, but fewer, buildings results in a decrease in overall roof area of $32 \%$ with the same decrease in rainwater harvesting potential (a mandatory requirement in Mumbai) resulting in less than half $(45 \%)$ the potential amount of rainwater per person (Figure 7).

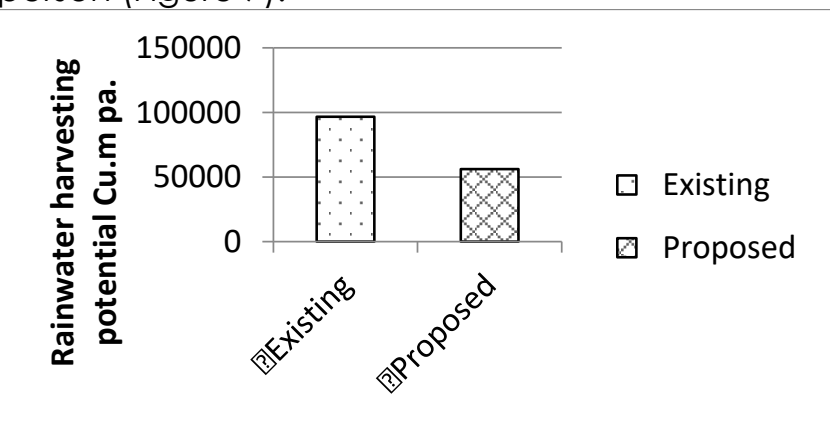

Figure 7. Comparison of rainwater harvesting potential.

\subsubsection{Sewage and wastewater}

Related to the additional water consumption is the sewage and wastewater generated by the new development. Sewage will be proportional to the increase in population. However, there will be significantly more wastewater related to the increased appliances and change in lifestyles.

The increased population on the site, with consequent increased wastewater and sewage, results in a sewage volume that has more than doubled (234\% increase) and reached 4.64 million litres per day. At present the sewage treatment plant for the zone (Worli) manages to treat less than $20 \%$ of the sewage, the rest is pumped directly to the sea without treatment. The increased sewage volume will result in less than $10 \%$ being treated unless there is sewage treatment on site.

\subsubsection{Electricity consumption}

Residential electricity is the largest consumer on the site and almost doubles (196\% increase) in the proposed development (Figure 8). This is combined with two new loads incurred by the development: i) lighting and ventilation to basement and podium car parks amounting to about $6 \%$ of the total residential load and ii) electricity use for other communal facilities that include; pumping water to the towers, lifts and lighting of corridors all of which amount to about $9 \%$ of the total residential load. 


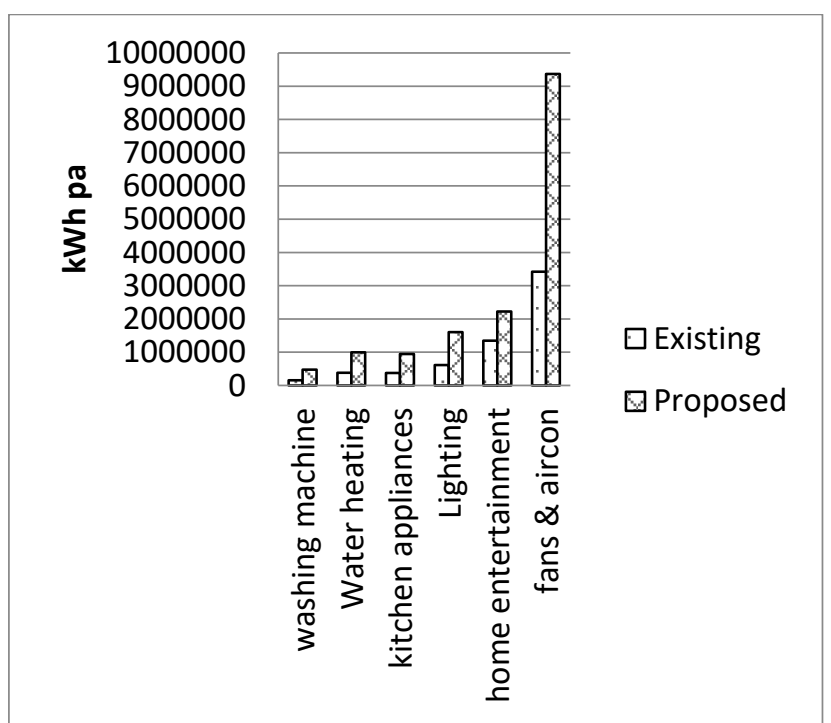

Figure 8. Comparison of residential electricity use.

The increased residential electrical load is due to several factors. The average floor area of each unit has almost doubled which results in additional lighting, fans and air-conditioning use. Dedicated water heating with larger volumes of water results in increased hot water usage especially with individual use of modern washing machines. Household appliances (e.g. microwaves, home entertainment and larger television screens) are likely to become commonplace and used more frequently. However, air-conditioning is likely to become the single largest consuming item as the demand for increased comfort and status that comes with airconditioning spreads (Tembhehar, 2011).

Electricity consumed by commercial and retail spaces will more than double ( $226 \%$ increase) in the new development (Figure 9). This is due mainly to the configuration of the commercial areas that, although having the same overall floor area as the existing development, have an external perimeter that has decreased by $63 \%$. This reduces both daylighting and cooling by natural ventilation resulting in increased use of fans and air-conditioning as well as artificial lighting (Byrd, 2012). Although the light fittings may tend to be more efficient, this is likely to be offset by the opportunity for increased display lighting in retail areas.

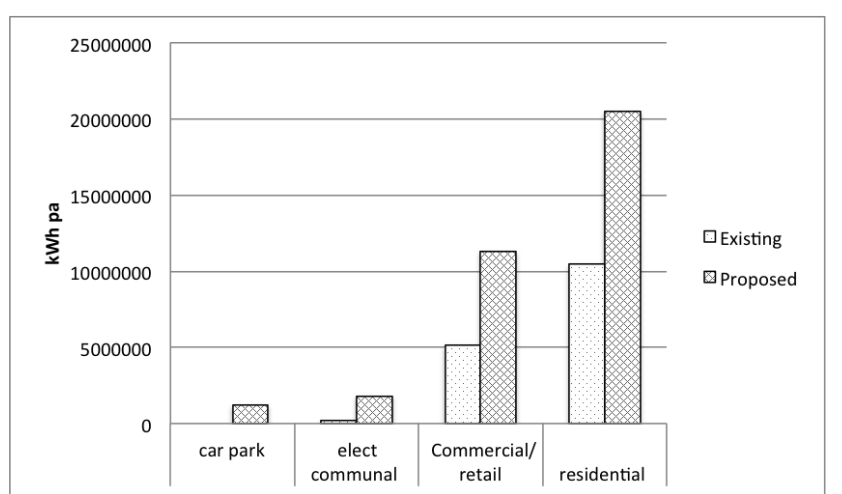

Figure 9. Comparison of all electricity uses.

Other miscellaneous appliances include the increased use of computers, display screens, electronic retail systems and signage. All of these not only directly increase the electrical load but also increase the cooling load within the retail and commercial spaces. Although refrigerators in retail areas may become more efficient, they are also likely to increase as the area will become more affluent and increase the demand for more pre-prepared food.

\subsubsection{Carbon emissions}

Considering only the carbon emissions in the operation of the development, the two main contributors are the carbon due to additional electricity generation and the emissions due to the additional private vehicles that can now be housed on the site (Figure 10). The carbon emissions in electricity generation in Maharashtra average about $0.9+\mathrm{CO}_{2} / \mathrm{MWh}$ reflecting the high proportion of coal-fired generation.

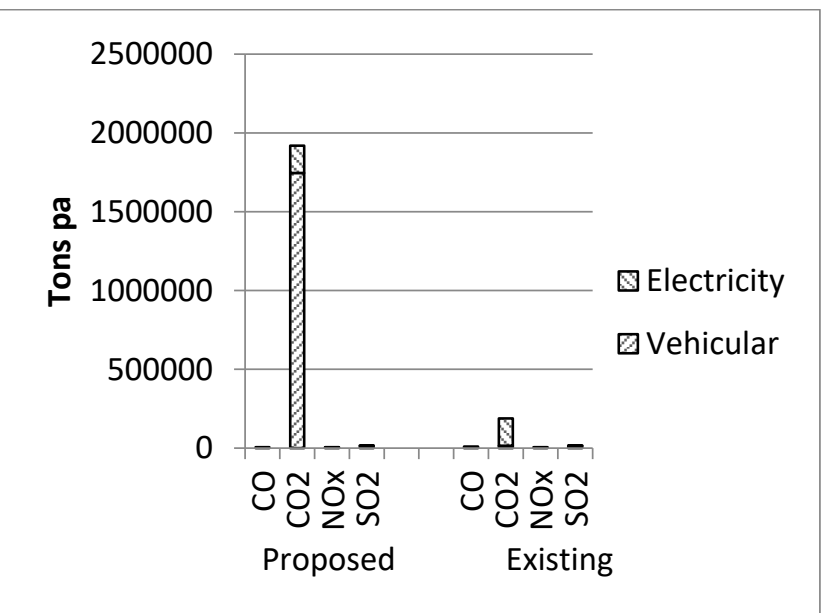

Figure 10. Comparison of Greenhouse gas emissions from electricity production and private vehicles.

The total additional electricity use for the proposed development is 18,326 MWhrs/year that equates to $16,494 \mathrm{tCO}_{2}$ per year. However, 
only a proportion of this is directly due to the nature of the development. The operation of the car parks (extraction fans and permanent lighting), lifts, pumping, common areas, airconditioning and lighting, for non-residential, and a proportion of air-conditioning for residential are directly attributable to the nature of the development.

This amounts to approximately half of the additional electricity load, making the development attributable to 8,247 $\mathrm{tCO}_{2}$ per year due to the increased electricity demand.

The amount of carbon emissions as a direct result of providing car parking spaces, where there were none previously, will depend on the type of vehicles and their travel patterns. The reduction in emissions due to changes of fuel (in particular CNG) has been assumed to be offset due to an increase in congestion as car ownership grows rapidly. Assuming $16 \mathrm{~km} /$ litre of fuel, the average carbon emissions per vehicle are $200 \mathrm{gCO}_{2} / \mathrm{km}$. It is assumed that $80 \%$ of the 1400 car parking spaces are occupied and used regularly and that the average travel distance is $6 \mathrm{~km}$ per day for recreation, occasional shopping and school drop-offs. This amounts to $25 \mathrm{~kg}$ per day or 491 $\mathrm{tCO}_{2}$ per year.

\subsubsection{Solid waste}

The per capita generation of solid wastes in Mumbai has been steadily increasing and reached $0.63 \mathrm{Kg} /$ person/day in 2004 (Mahadevia, Pharate, \& Mistry, 2005). It should be noted that in addition to the land required for dumping the waste, a considerable amount of energy is spent in sorting, transporting and processing the waste in addition to the greenhouse gases released from their decomposition. The overall increase in solid waste is anticipated to increase by $30 \%$ per capita due largely to increased affluence (Figure 11).

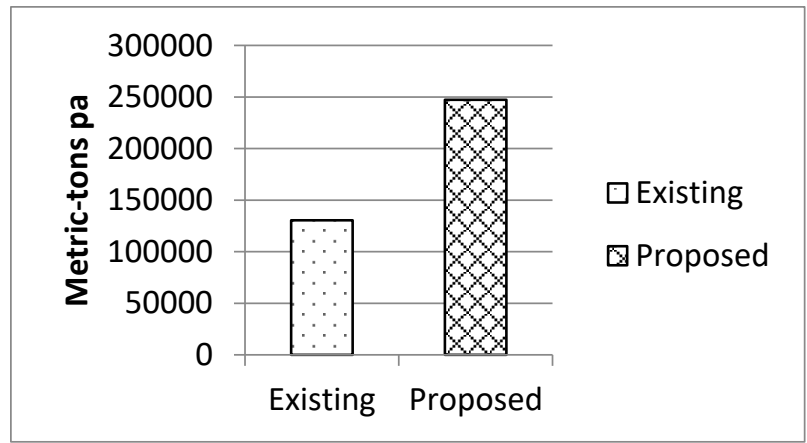

Figure 11. Comparison of solid waste generated.

\section{Extrapolating the results across the Island City} The results above are for the 16.5-acre site, Bhendi Bazaar that has been named as an exemplar development for the proposed 'smart' cities in India. To investigate what the impact would be if the development was replicated across a city, the analysis was extrapolated across Mumbai's Island city.

The development potential of the City is related to the number of 'cessed' properties that can be demolished and redeveloped. Figure 12 indicates the increase in population in each of the City's wards should the Bhendi Bazaar project be replicated. The different proportions of increased growth relate directly to the proportion of cessed properties in each ward. The case study area considered above is in Ward C.

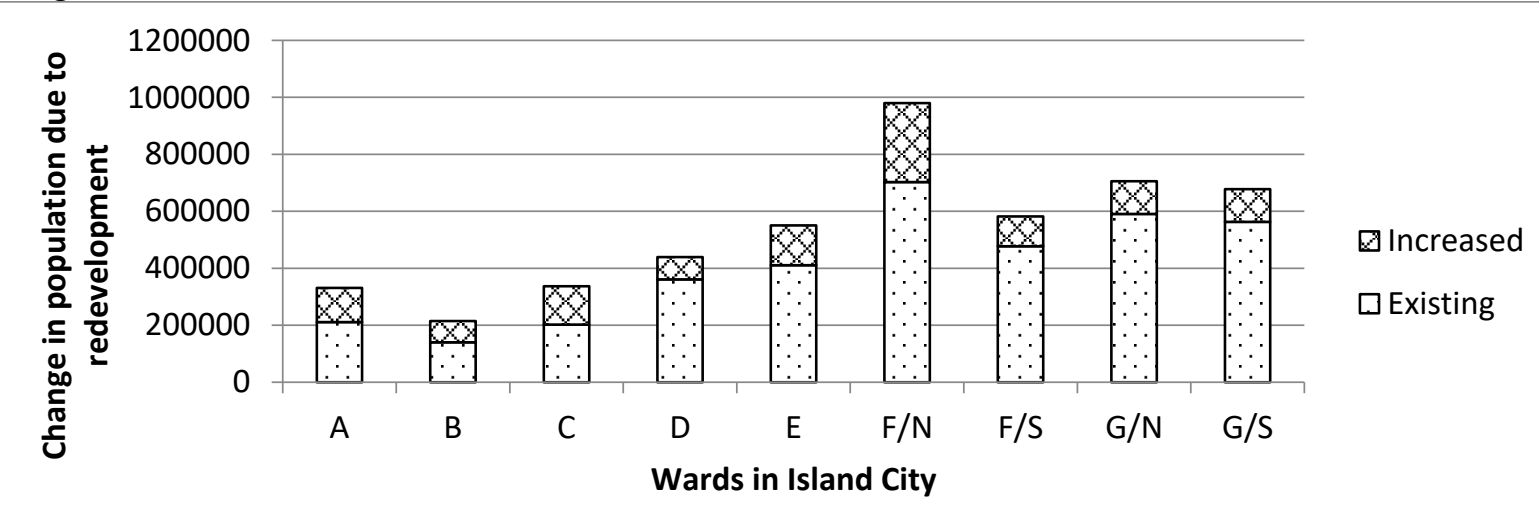

Figure 12. Increased population across the Island City if 'cessed' properties are demolished for the 'smart' development proposals. 
Overall, the results indicate that the intensification policy in the Island City would result in 1677 new tower blocks averaging 40 storeys high, 51,780 additional car parking, a reduction in open space per person from 1.27 to $1.15 \mathrm{sqm}$, a new $100 \mathrm{MW}$ power station (probably coal-fired (Gosh, 2010)), a new 100 million litres per day dam to supply water, 160 million litres per day of sewage to be processed, 3570 tons per day of CO2 production and many more adverse impacts. All this will be added to a City that, due to inadequate resources and difficult geography, already systematically rations electricity by blackouts (Byrd \& Matthewman, 2014a), rations water to a few hours per day, and where $80 \%$ of sewage is untreated and washes up on the shoreline (Mandal \& Byrd, 2013).

\subsection{Per capita impact}

In order to compare the environmental impact of the new development with the existing, it is useful to measure it in terms of change (increase or decrease) per capita or unit floor area.

Since the redevelopment of the site results in an increase in population of about $25 \%$ greater than the existing, the consumption per capita results in the following.

Water consumption as well as wastewater (including sewage) per capita is likely to increase by $155 \%$ and potential rainwater harvesting is likely to reduce to less than half (45\%).

Residential electricity consumption per capita is predicted to increase by $30 \%$ while electricity in commercial and retail spaces will more than double per unit of floor area (226\% increase)

Carbon dioxide emissions, due to total electricity consumption, more than double which results in CO2 emissions per capita increasing by $43 \%$. However, C02 emissions, due to transport increase by $176 \%$ per capita. Solid waste increases by about $100 \%$.

\section{Discussion}

With policies of compaction and constraints on the dispersal of cities, urban form will inevitably grow vertically. With verticality grows dependence on centralised 'flows' of energy, water supplies and waste disposal. Dependency leads to vulnerability and insecurity and, while suburbia offers some degree of resilience by its ability to collect energy and water from individual roofs and food from individual gardens, vertical urban form offers little resilience (Byrd \& Matthewman, 2014b).

While demand is increasing for resources to 'feed' the metabolism of Mumbai, supply from the hinterland is struggling. In the case of electricity supply, the state of Maharashtra consumes almost $12 \%$ of India's electricity, having the highest consumer base in the country, it also tops the list for more deficit compared to other states. Consumption of electricity is growing faster than production capacity. The depletion of 'easy to find' coal combined with higher energy demands from industry and air-conditioning is leading to electricity blackouts on a regular basis (BBC News, 2002; BS Reporter, 2006; Rediff News, 2007).

In the case of water supply, the city of Mumbai is facing water shortages, with parts of the city receiving direct supply of water for only a few hours in the day and water connections to any new tower, clusters or townships being suspended till the Middle Vaitarna water supply project is completed (Sen, 2009). In the case of solid waste, most of Greater Mumbai's collected solid waste is disposed of as mere dumping and levelling at the landfill sites at Deonar, Mulund and Gorai that have almost outlived their carrying capacity. Though the Government of Maharashtra has allotted a disposal site in Kanjur Marg, it is likely to be inadequate for the projected solid waste generation (MCGM, 2005 to 2025 a).

In the case of drainage, the discharge of all the storm water and treated sewage is into the Arabian Sea. Tidal variation has a major bearing in the system of storm water drainage resulting in flooding and water logging during heavy rains and high tides (MCGM, 2005 to 2025 b). This is likely to get worse with the risk of sea level rise due to climate change. The sewage system of Mumbai is inadequate, resulting in discharge of large amounts of untreated sewage into creeks, causing degradation of coastal water quality and contamination of the adjoining beaches and seafronts (Kumar, Subramaniam, \& Patil, 2000).

The pursuit of cities to become 'smart', 'worldclass', 'liveable', 'green' or 'eco', has been promoted alongside increased population densities and urban compaction. This planning 
goal must reach a point where resources are inadequate for the fully functioning metabolism of a city. While case studies such as Bhendi Bazaar offer an exemplar for the 100 'smart' cities planned by the Indian Government in terms of increased density, improved image and urban regeneration, they do not offer an answer to the problems of providing an adequate infrastructure to support the metabolism of such developments if they were to be significantly replicated.

\section{Conclusion}

Using the Indian Government's own definition of a 'smart city' and the exemplar development that is put forward by them, this research has analysed the claim that the exemplar is 'smart'. The research has not only investigated the exemplar development but has extrapolated the implications should such a type of development be implemented across the Island City of Mumbai or elsewhere in India.

Data on the redevelopment proposals has been obtained from Governmental agencies, consultants for the redevelopment project and from site surveys. The environmental analysis is based on the 'extended urban metabolism' model with data based partly on empirical evidence from precedents and supported by calculation from first principles.

The results indicate that there is a significant adverse impact on the environment and that the increased metabolism, and hence detrimental environmental impact, increases at a greater rate than population increase. On this basis, this exemplar development does not support the case for calling the proposals for Mumbai 'smart' or 'sustainable'.

\section{Acknowledgments}

This research did not receive any specific grant from funding agencies in the public, commercial, or non-for-profit sectors

\section{References}

Albino, V., Berardi, U., Dangelico, R. (2015) Smart Cities: Definitions, Dimensions, Performance, and Initiatives. Journal of Urban Technology. Vol. 22, No. 1, 3-21.
BBC News. (2002, May 30) Indian state curbs electricity to industry BBC News. Retrieved from http://news.bbc.co.uk/2/hi/business/2016611.st $\mathrm{m}$

Bertaud, A. (2013, June) Mumbai Far/Fsi Conundrum: The perfect storm: the four factors restricting the construction of new floor space in Mumbai. Retrieved from http://alainbertaud.com/wpcontent/uploads/2013/06/AB-Mumbai-FSIConundrun-Revised_June-2013_kk-abl.pdf

BS Reporter. (2006, 17 October). Mumbai facing power shortage, Business Standard Retrieved from http://www.businessstandard.com/india/news/mumbai-facingpower-shortage/261974/

Byrd, H. (2012) Post-occupancy evaluation of green buildings: the measured impact of overglazing. Architectural Science Review, 55 (3). pp. 206-212

Byrd, H., \& Nash, E. (2012) Maths and myths behind a low carbon Auckland. Working Paper. Transforming Cities, Auckland. Retrieved from http://eprints.lincoln.ac.uk/7822/

Byrd, H. \& Matthewman, S. (2014a) Lights out: the dark future of electric power. New Scientist (2968).

Byrd, H. \& Matthewman, S. (2014b) Exergy and the city: the technology and sociology of power (failure). Journal of Urban Technology, 21 (3). pp. 85-102.

Byrd, H., Ho, A., Sharp, B. \& Kumar N., N. (2013) Measuring the solar potential of a city and its implications for energy policy. Journal of Energy Policy, 61. pp. 944-952.

Census of India. (2011a). Census 2011. Retrieved from http://www.census2011.co.in

Council on Tall Buildings and Urban Habitat (2010) Remaking Sustainable Cities in the Vertical Age. Retrieved from http://www.ctbuh.org/Events/Conferences/M umbai2010/tabid/1391/language/enUS/Default.aspx

Gosh, S. (2010) Status of thermal power generation in India-Perspectives on capacity, generation and carbon dioxide emissions. Energy Policy 38, pp6886-6899 
Nia, H. (2017). Identity in Changing Context: Factors of losing Identity in new developed part of the city of Famagusta, North Cyprus. Contemporary Urban Affairs, 1(2), 1-10. Doi: 10.25034/ijcua.2017.3644

Gosh, S., Vale, R. \& Vale, B. (2006.)Domestic energy sustainability of different urban residential patterns: a New Zealand approach. International Journal of Sustain- able Development 9(1), 16-37.

Government of India (2015a) Smart Cities Mission; strategy. Retrieved from http://smartcities.gov.in/writereaddata/Strate gy.pdf

Government of India. (2015b) Smart Cities Mission; what is a smart city. Retrieved from. http://smartcities.gov.in/writereaddata/What\% 20is\%20Smart\%20City.pdf

Hammer, S., Kamal-Chaovi, L. \& Robert, A. and M. Plouin. (2011) Cities and Green Growth: A Conceptual Framework,

OECD Regional Development Working Papers 08, OECD Publishing, 2011.

Kumar, R., Subramaniam, J., \& Patil, D. (2000). Water Quality Modelling of Municipal Discharges from Sea Outfalls, Mumbai. Environmental Monitoring and Assessment (62), 119-132.

Leung, A. (2016, February 8) The Key to Green Cities and Mindsets: Densification. Meeting of the Minds. Retrieved from. http://cityminded.org/the-key-to-green-citiesand-mindsets-densification-14887

Mandal, A. (2015) Density, intensification and urban Redevelopment: The metabolism of Mumbai. $\mathrm{PhD}$ thesis, The University of Auckland https://researchspace.auckland.ac.nz/handle /2292/25956

Mandal, A. \& Byrd, H. (2013) Limits to urban growth: the case of Mumbai. In: Twentieth International Seminar on Urban Form (ISUF), 17-20 July 2013, Brisbane, Queensland, Australia.

MCGM. (2005 to 2025a). Chapter 2: Mumbai today: Present status (2.7. Solid Waste Management) Greater Mumbai City Development Plan. Mumbai.
MCGM. (2005 to 2025b). Chapter 2: Mumbai today: Present status (2.13. Urban Basic Services) Greater Mumbai City Development Plan. Mumbai.

Myors, P., O'Leary, R. \& Helstroom, R. (2005, October 8) Multi-unit residential buildings energy and peak demand study. Report for Energy Australia and NSW Dept. of Infrastructure, Planning and Natural Resources. Retrieved from.

http://www.ausgrid.com.au/Common/Ournetwork/Demand-management-and-energyefficiency/Energy-use-facts-andfigures/ /media/Files/Network/Demand\%20M anagement/Energy\%20use\%20resources/Netw orks_multi_unit_sumrep_Oct08.pdf

Newman, P., Birrell, B., Holmes, D., Mathers, C. Newton, P., Oakley, G. \& Tait, D. (1996). Human Settlements Australia: State of the Environment: Environment Australia, Dept. of the Environment.

Newman, P. \& Kenworty, J. (1989) Gasoline consumption and cities. Journal of the American Planning Association. 55(1), 24-37

Perkins, A. Hamnett, S., Pullen, S., Zito, R. \& Trebilcock, D. (2009) Transport, Housing and Urban Form: The Life Cycle Energy Consumption and Emissions of City Centre Apartments Compared with Suburban Dwellings. Urban Policy and Research 27,4,377396

Rathod, K (2012) Mumbai's realty: going vertical with a vengeance. Retrieved from. http://www.dnaindia.com/mumbai/reportmumbai-s-realty-going-vertical-with-avengeance- 1745748

Rediff News. (2007, 03 April). Can Mumbai escape power cuts?, Rediff News (Business Standard). Retrieved from http://www.rediff.com/money/2007/apr/03gu estl.htm

Remaking of Mumbai Federation. (2008-2014). Cessed properties: Historical context. Need for remaking. Retrieved from http://www.romf.org/need\%20for\%20remaking /cessed\%20properties.aspx

Rode, P., Keim, C., Robazza, G., Viejo, P. \& 
Schofield, J (2014): Cities and Energy: Urban Morphology and Residential Heat Energy Demand. Environment and Planning $B$ : Planning and Design 41 (1): 138 - 162

Sen, S. (2009, 12 December). No water for new Mumbai towers, Times of India

Steadman, P. (2015) High-Rise Buildings: Energy and Density. Retrieved from http://www.createstreets.com/essays/4589645 470

Sridhar, K. (2010) Impact of Land Use Regulations: Evidence from India's Cities. Urban Studies, $47(7), 1541-1569$

sustainablecitiesnetwork. (2011 July 13). How much green space does your city have? (originally by Marcelino Vazquez). Retrieved from http://blog.sustainablecities.net/201 1/07/13/h ow-many-metres-of-green-space-does-yourcity-have/

Tembhekar, C. (2009, December 23). ACs eat up $40 \%$ of city's total power consumption, The Times of India. Retrieved from http://timesofindia.indiatimes.com/city/mumb ai/ACs-eat-up-40-of-citys-total-powerconsumption/articleshow/5368121.cms?referra I=PM A

Tembhekar, C. (2011) Thirst for power will see demand in Mumbai rise by $886 \mathrm{MW}$. The Times of India. Retrieved from http://articles.timesofindia.indiatimes.com/201 1-10-27/mumbai/30327683_1_powerrequirement-electricity-generation-capacitypower-generation

Yelda, S. (2006) Dynamics of environmental problems in Mumbai. Journal of Clean Technology and Environmental Policy, 8: 182187 